\title{
KNOWLEDGE AND ATTITUDE TOWARDS CORPORAL PUNISHMENT AMONG PRIMARY SCHOOL TEACHERS OF BIRATNAGAR SUB-METROPOLITAN CITY, MORANG, NEPAL
}

\author{
Shrestha $M^{1}$, Badhu $A^{2}$, Shah $T^{2}$, Baral $D^{3}$
}

\section{Affiliation}

1. Lecturer, College of Medical and Allied Sciences, Purbanchal University, Gothgaon, Morang, Nepal

2. Professor, Department of Community Health Nursing, College of Nursing, B. P. Koirala Institute of Health Sciences, Dharan, Sunsari, Nepal

3. Assistant Professor, School of Public Health and Community Medicine, Dharan, Sunsari, Nepal

\section{ARTICLE INFO}

Article History
Received : 01 August, 2017
Accepted : 14 September, 2017
Published : 31 December, 2017

(c) Authors retain copyright and grant the journal right of first publication with the work simultaneously licensed under Creative Commons Attribution License CC - BY 4.0 that allows others to share the work with an acknowledgment of the work's authorship and initial publication in this journal.

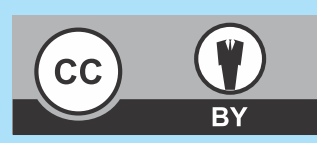

ORA 38

DOI: http://dx.doi.org/10.3126/bjhs.v2i3.18936

\author{
* Corresponding Author \\ Menuka Shrestha \\ Lecturer \\ Purbanchal University \\ College of Medical and Allied Sciences \\ Gothgaon, Morang \\ E-mail:mennusb@gmail.com
}

\section{Citation}

Shrestha M, Badhu A, Shah T, Baral D. Knowledge and Attitude Towards Corporal Punishment among Primary School Teachers Of Biratnagar Sub-metropolitan City, Morang, Nepal BJHS 2017;2(3)4:248-254.

\section{ABSTRACT}

\section{Introduction}

School experience has remarkable effect on emotional and personal development of children. Intended developments can be achieved through qualified education. It is quite a challenging fact that corporal punishment is still being used in the schools of Nepal as reported in the news papers and other literature. However, there is little information about the knowledge and attitude of teachers towards corporal punishment.

\section{Objective}

To assess knowledge and attitude and to identify the association between the selected variables and knowledge and attitude towards corporal punishment among primary school teachers of Biratnagar Sub-Metropolitan City.

\section{Methodology}

Descriptive cross sectional study was conducted in Biratnagar Sub-metropolitan City, Nepal. A total of 160 primary school teachers were included using total enumeration sampling technique. Data were collected by using selfadministered, semi-structured questionnaire and Likert Scale. Written consent was taken from each participant and ethical approval was taken from Institutional Review Board of B.P Koirala Institute of Health Sciences. Statistical analysis was done using SPSS.

\section{Results}

All respondents had heard about corporal punishment but most of them were not clear about the rules against corporal punishment in schools. The mean percentage score of knowledge was $58.81 \pm 19.34$ and for attitude 56.30 \pm 6.98 . There was a positive correlation $(r=0.455, p<0.001)$ between knowledge and attitude towards corporal punishment. Majority of respondents scored less than the mean score. Females and government school teachers' knowledge and attitude were found to be more positive.

\section{Conclusion}

The study revealed that the teaching experience, training regarding corporal punishment and childhood experience of corporal punishment were significantly associated with teachers' knowledge and attitude. The government should begin public awareness campaigns to disseminate information on corporal punishment as violence through different media.

\section{KEYWORDS}

Corporal punishment, primary school, teacher's attitude, knowledge 


\section{INTRODUCTION}

Children are the most valuable asset for any society. The future of the country depends upon the present children. If the children do not develop in a proper way, the future of the country will be ruined. It is the responsibility of the parents, teachers and the society to bring up the children in a constructive way. ${ }^{1}$

Childhood is a delicate, sensitive and vulnerable period which requires considerate care and understanding. Ironically, this vital phase is overlooked in our society where most of the parents and teachers, by their very nature think that it is important to punish the children in order to tame their activities and to guide them to right track. This is evident from the study done by Shrestha and Thakuri in 2004 , which reported that $60 \%$ teachers believe students, cannot be disciplined without punishment. ${ }^{2}$

Nepal is among 113 countries who prohibit corporal punishment in schools. The Convention on the Rights of the Child (CRC) demands that children be respected as human beings with the right to dignity and physical integrity. ${ }^{3}$

The problem is common both in developed and developing countries. ${ }^{4}$ As per the Global initiative to End All Corporal Punishment of Children, 90 countries continue to allow teachers to legally use corporal punishment and even in the countries where corporal punishment is legally banned, it is often poorly enforced..$^{5}$

Corporal punishment is being used as a tool of discipline in homes, schools, day care homes and in work places. There is no law that prevents corporal punishment from being used in the home and schools. The offences Against Children's Bill 2006 seeks to correct this gap. States are now enacting laws to prevent corporal punishment in schools. Many research evidence leads to the conclusion that it is an ineffective method of discipline with injurious effect on the physical and mental health of those inflicted. But no systematic study of the phenomenon was attempted to document the knowledge and attitude of teachers towards its use. The main purpose of this study is to find out the knowledge and attitude towards corporal punishment among primary school teachers of Biratnagar SubMetropolitan City.

\section{METHODOLOGY}

This is a descriptive cross-sectional study carried out in the primary schools of Biratnagar Sub-metropolitan City from $1^{\text {st }}$ October 2012 to $30^{\text {th }}$ July, 2013. A list of government and private primary schools of Biratnagar Sub-Metropolitan City was obtained from the District Education Office, Morang. All the primary school teachers were enumerated who met the inclusion criteria. The total sample size was 160. Written consent was taken from each participant and ethical approval was taken from Institutional Review Board of BP Koirala Institute of Health Sciences.

\section{Data Collection Tools and techniques}

A self-prepared, semi-structured questionnaire and Likert Scale was used to assess the knowledge and attitude towards corporal punishment respectively after reviewing various literatures and consulting the subject experts.

Questionnaire related to knowledge on different aspects of corporal punishment, consisting 15 items where 10 items had scores to assess the knowledge and rests were descriptive types of questions. Five point Likert scale; having 10 items, consisting of four positively and six negatively phrased items were used to assess the attitude of respondents regarding corporal punishment. For that, a revised Valicer Attitude towards Violence Scale (VATVAS) and Likert Scale developed by Simiyu Christine N. were modified and adopted. The tools were modified with consultation of three subject experts. Responses were reported on a five point continuum from "strongly agree" to "strongly disagree". Respondents indicated the degree of their agreement or disagreement with each statement on a five point Likert scale from 1 (strongly agree) to 5 (strongly disagree).

The total possible score range of 10 - 50. The individual scores were added up to form an overall attitude score for each respondent. The degrees of strongly agree and agree were summated to yield the net agreement while the degree of disagree and strongly disagree were summated to yield the net disagreement for the sake of determining their frequency distribution. Higher score indicating a higher knowledge and positive attitude towards corporal punishment.

The questions were developed initially in English language then translated into Nepali and reverse translation was done with consulting language experts. Ethical principles were considered and followed throughout the study to protect the right of the participants.

\section{RESULTS}

The respondents were found in the ratio of one male teacher to three females (40:120). Significant percentage $(40.6 \%)$ of the respondents was less than 30 years. More than half $(61.9 \%)$ of respondents were from upper caste groups. Majorities (85.0\%) of respondents were Hindus, married $(77.5 \%)$ and had children (92.7\%) with less than and equals to two children (80.9\%). Significant percentage $(46.3 \%)$ of respondents had completed intermediate level of education. Fifty percent of respondents' family income lies between Rs. 10,001-20,000/month. Majorities (70.0\%) of respondents were exposed to corporal punishment in childhood. Among them $66.2 \%$ had experienced canning as corporal punishment during their school life. (Table 1)

More than half (53.8\%) of respondents were from government school. Most of the respondents (66.9\%) had teaching experience less than 10 years. Majorities of respondents $(86.9 \%)$ had not received training regarding corporal punishment. Teachers who taught $\leq 5$ class per day were (60.0\%) with $55.0 \%$ of them were involved in extra activities. Among them, more than half $(62.5 \%)$ of respondents took tuition during extra time and $55.7 \%$ were engaged in extra activities 2-4 hours/day. Nepali was $22.5 \%$, Mathematics $21.9 \%$, English $18.8 \%$ teachers. 
Table 1: Socio-Demographic Characteristics of Respondents $n=160$

\begin{tabular}{|c|c|c|c|}
\hline Characteristics & Categories & requency & Percentage \\
\hline \multirow{2}{*}{ Gender } & Male & 40 & 25.0 \\
\hline & Female & 120 & 75.0 \\
\hline \multirow{3}{*}{ Age in years } & $<30$ & 65 & 40.6 \\
\hline & $30-40$ & 55 & 34.4 \\
\hline & $>40$ & 40 & 25.0 \\
\hline \multicolumn{4}{|c|}{ Mean age \pm SD : $34.32 \pm 10.35$} \\
\hline \multirow{6}{*}{$\begin{array}{l}\text { Caste/Ethnic } \\
\text { Group }\end{array}$} & Dalit & 6 & 3.8 \\
\hline & Disadvantaged Janajatis & 21 & 13.1 \\
\hline & Disadvantaged non Dalit Tarai caste & 9 & 5.6 \\
\hline & Religious Minorities & 13 & 8.1 \\
\hline & Relatively advantaged Janajatis & 12 & 7.5 \\
\hline & Upper caste groups & 99 & 61.9 \\
\hline \multirow{4}{*}{ Religion } & Hindu & 136 & 85.0 \\
\hline & Muslim & 13 & 8.1 \\
\hline & Christian & 6 & 3.8 \\
\hline & Kirant & 5 & 3.1 \\
\hline \multirow{2}{*}{ Marital status } & Married & 124 & 77.5 \\
\hline & Unmarried & 36 & 22.5 \\
\hline \multirow{2}{*}{ Have children } & Yes & 115 & 78.9 \\
\hline & No & 45 & 28.1 \\
\hline \multirow{2}{*}{$\begin{array}{l}\text { Number of } \\
\text { children }\end{array}$} & $\leq 2$ & 93 & 80.9 \\
\hline & $>2$ & 22 & 19.1 \\
\hline \multicolumn{4}{|c|}{ Mean number of child \pm SD $(1.96 \pm 0.78)$} \\
\hline \multirow{3}{*}{$\begin{array}{l}\text { Level of } \\
\text { education }\end{array}$} & S.L.C & 46 & 28.8 \\
\hline & Intermediate level & 74 & 46.2 \\
\hline & Bachelor and above & 40 & 25.0 \\
\hline \multirow{2}{*}{$\begin{array}{l}\text { Childhood } \\
\text { experience } \\
\text { of CP }\end{array}$} & Yes & 112 & 70.0 \\
\hline & No & 48 & 30.0 \\
\hline \multirow{4}{*}{$\begin{array}{l}\text { Types of CP they } \\
\text { had experienced } \\
\text { during childhood* } \\
(n=112)\end{array}$} & Canning & 100 & 66.2 \\
\hline & Ear pulling & 19 & 12.6 \\
\hline & * Knelling down & 20 & 13.3 \\
\hline & Up-down by grasping ear & 12 & 7.9 \\
\hline
\end{tabular}

*Multiple responses

Not completing homework (60.0\%) was the common reasons to corporally punished students in schools. Ear pulling (63.1\%) was the most prevalent corporal punishment in school followed by beating $(58.8 \%)$. Knelling down $(48.8 \%)$ and majority $(70.6 \%)$ of respondents stated that boys are mostly getting corporal punishment than girls (fig.1).

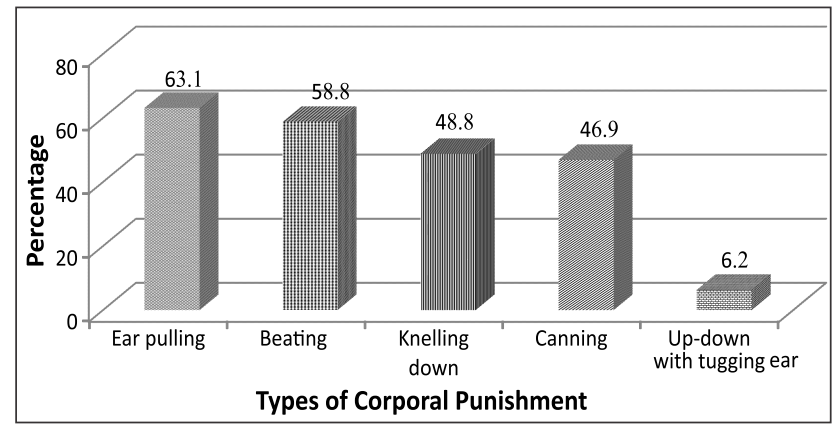

Figure 1: Types of Corporal Punishment

All of the respondents had heard about corporal punishment in school through different media. Among them, significant percentage $(31.9 \%)$ of respondents received information from their colleagues followed by newspaper (22.5\%), T.V (19.4\%). More than half (58.1\%) of the respondents did not know what may be the physical effects of corporal punishment while $41.9 \%$ of respondents were aware of it. On questioning those who were aware about the effects of corporal punishment, $52.3 \%$ of respondents stated that injury to the affected site followed by fracture of extremities (40.0\%), handicapped (38.4\%) and ear burst $(9.2 \%)$ are the major effects. Majority $(75.0 \%)$ of the respondents were unaware about the effects of corporal punishment on mental health of children while $21.9 \%$ were aware and equal number of the respondents stated that depression, fearfulness $(28.6 \%)$, suicide (22.8\%) and mental illness $(20.0 \%)$ are the major effects. Similarly, more than half (68.1\%) of the respondents did not know the effects of the corporal punishment on the child's growth and developments.

Majority (68.8\%) of the respondents stated that training to teachers regarding corporal punishment was the best option to end corporal punishment from the schools while $53.8 \%$ mentioned that parents must be involved in reforming students. (Table 2)

\begin{tabular}{|c|c|c|c|}
\hline \multirow[t]{2}{*}{ Variables } & Categories & Frequency & Percentage \\
\hline & Training to teachers & 110 & 68.8 \\
\hline \multirow{3}{*}{$\begin{array}{l}\text { Ways to end } \\
\text { corporal } \\
\text { punishment } \\
\text { in school }\end{array}$} & $\begin{array}{l}\text { Parents must be involved in } \\
\text { reforming students }\end{array}$ & 86 & 53.8 \\
\hline & $\begin{array}{l}\text { Parents must be regularly informed } \\
\text { about their children's progress in } \\
\text { class }\end{array}$ & 99 & 61.9 \\
\hline & $\begin{array}{l}\text { There is no way to end the use of } \\
\text { corporal punishment in schools }\end{array}$ & 4 & 2.5 \\
\hline
\end{tabular}

\section{Multiple responses}

Vast majorities (90.0\%) of respondents were aware about the rules against corporal punishment but on questioning about the rules, majorities (79.9\%) of respondents reported that they didn't know. Most (93.1\%) of respondents agreed that corporal punishment should be banned in schools but for that almost all respondents (98.8\%) felt need of training. When respondents were asked whether "Corporal punishment is good for discipline" the majority (53.1\%) agree with the statement while (41.9\%) disagree with it. When the respondents were asked whether "corporal punishment makes pupils to higher marks", more than half (54.4\%) of the respondents said it does while $(33.7 \%)$ said it does not. When the respondents were subjected to the statement "corporal punishment makes pupils work hard", the more (40.0\%) agreed while (31.2\%) disagreed.

On the statement whether corporal punishment creates feeling of anger and revenge in children, the majority $(61.2 \%)$ of the teachers tended to disagree. On the statement "Corporal punishment is the only language children understand", most (45.0\%) of the respondents agreed while disagreed $(26.3 \%)$ and $28.8 \%$ respondents were unsure. On the statement "spare the rod spoils the child", more than half (56.9\%) of the respondents showed agreement with this statement. On the question of whether corporal punishment is violence against children, most (46.9\%) of the respondents disagreed that it was.

When the respondents were subjected to the statement, "Punishing a child physically when she/he deserves it will 
make him/her a responsible and mature adult" majority (56.9\%) of respondents agreed while $27.5 \%$ disagreed with the statement. On the statement abolition of all forms of corporal punishment from school can be a good idea the majority $(44.4 \%)$ of respondents disagreed with this idea while (34.4\%) agreed. (Table 3 )

Table 3: Attitude towards Corporal Punishment $n=160$

Statement

Agree No. $(\%)$

Undecided No. (\%)

Disagree No. (\%)

Corporal punishment is good for discipline.

$\begin{array}{lcc}85(53.1) & 8(5.0) & 67(41.9) \\ 87(54.4) & 19(11.9) & 54(33.7) \\ 64(40.0) & 46(28.8) & 50(31.2) \\ 49(30.6) & 37(23.1) & 74(46.3) \\ 43(26.9) & 19(11.9) & 98(61.2) \\ 72(45.0) & 46(28.7) & 42(26.3) \\ 91(56.9) & 32(20.0) & 37(23.1) \\ 63(39.4) & 22(13.7) & 75(46.9) \\ 91(56.9) & 25(15.6) & 44(27.5) \\ 55(34.4) & 34(21.2) & 71(44.4)\end{array}$

Corporal punishment makes pupils get higher marks in tests and exams.

Corporal punishment makes pupils work hard.

Corporal punishment makes pupils feel fearful and degraded.

Corporal punishment creates feelings of aggression or revenge in children.

Corporal punishment is the only language children understand.

Spare the rod spoils the child.

Corporal punishment is violence against

children.

Punishing a child physically when she/he

deserves it will make him/her a responsible and mature adult.

Abolition of all forms of Corporal punishment in

school is a good idea.

punishment during childhood. Similarly, there was significant association of attitude with age $(p=0.030)$, working area $(p=0.002)$ training $(p=0.001)$, teaching experience $(p=0.032)$, involvement in extra activities and experience of

corporal punishment (0.006) in childhood. (Table 4)

The mean percentage score of knowledge was $58.81 \pm 19.34$ and for attitude $56.30 \pm 6.98$. It was found that there was significant association of knowledge with gender $(p=0.045)$, education $(p=0.002)$, family income $(p=0.003)$, training, teaching experience and experience of corporal

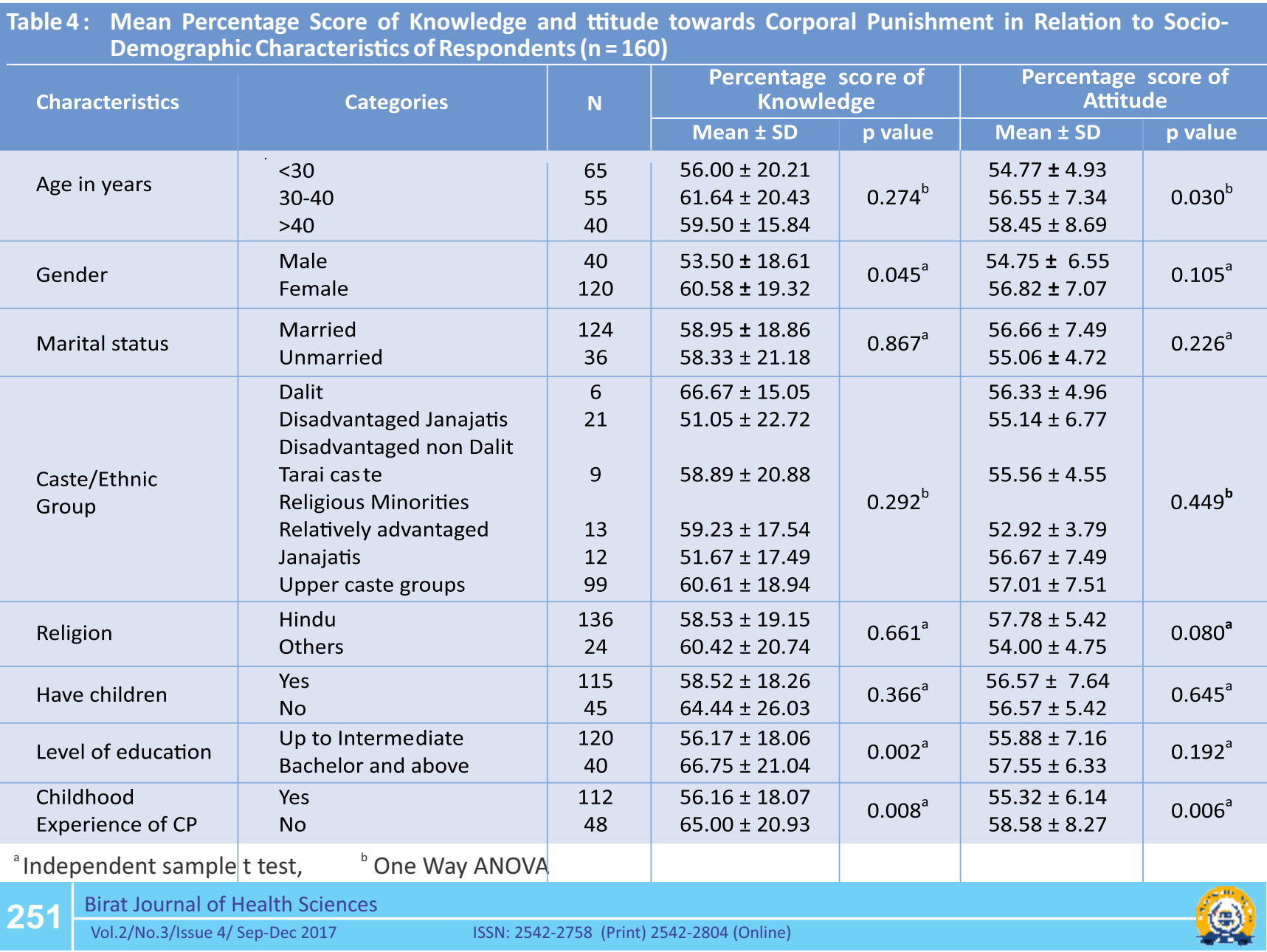


The study revealed that training and teaching experience was significantly associated with knowledge and attitude. The result suggests that knowledge of the respondents had significantly increased with training and teaching experience. Working area and involvement in extra activities were associated to attitude but not with knowledge. Negative attitudes towards corporal punishment were more among private school teachers than that of government. Positive attitude was more among the teachers who were involved in music as extra activities than sports, business and tuition. Remaining work related variables were not significantly associated with knowledge and attitude. (Table 5)

Table 5 : Mean Percentage Score of Knowledge and Attitude toward Corporal Punishment in Relation to Work Related Characteristics of Respondents $n=160$

\begin{tabular}{|c|c|c|c|c|c|c|}
\hline \multirow[t]{2}{*}{ Characteristics } & \multirow[t]{2}{*}{ Categories } & \multirow[t]{2}{*}{$\mathbf{n}$} & \multicolumn{2}{|c|}{$\begin{array}{l}\text { Percentage score of } \\
\text { Knowledge }\end{array}$} & \multicolumn{2}{|c|}{$\begin{array}{c}\text { Percentage score of } \\
\text { Attitude }\end{array}$} \\
\hline & & & Mean \pm SD & p value & Mean \pm SD & P value \\
\hline Working area & $\begin{array}{l}\text { Government } \\
\text { Private }\end{array}$ & $\begin{array}{l}86 \\
74\end{array}$ & $\begin{array}{l}60.12 \pm 19.00 \\
57.30 \pm 19.74\end{array}$ & $0.360^{a}$ & $\begin{array}{l}57.84 \pm 7.98 \\
54.51 \pm 5.10\end{array}$ & $0.002^{a}$ \\
\hline Training received & $\begin{array}{l}\text { Yes } \\
\text { No }\end{array}$ & $\begin{array}{c}21 \\
139\end{array}$ & $\begin{array}{l}83.81 \pm 13.22 \\
55.04 \pm 17.21\end{array}$ & $<0.001^{a}$ & $\begin{array}{l}61.14 \pm 8.06 \\
55.57 \pm 6.53\end{array}$ & $0.001^{a}$ \\
\hline $\begin{array}{l}\text { Teaching experience } \\
\text { in years }\end{array}$ & $\begin{array}{l}<10 \\
10-20 \\
>20\end{array}$ & $\begin{array}{c}107 \\
36 \\
17\end{array}$ & $\begin{array}{l}56.64 \pm 19.32 \\
64.44 \pm 20.76 \\
60.59 \pm 13.90\end{array}$ & $0.041^{b}$ & $\begin{array}{l}55.20 \pm 6.12 \\
57.89 \pm 7.18 \\
59.88 \pm 9.81\end{array}$ & $0.031^{b}$ \\
\hline $\begin{array}{l}\text { Number of classes } \\
\text { taken/day }\end{array}$ & $\begin{array}{l}\leq 5 \\
>5\end{array}$ & $\begin{array}{l}96 \\
64\end{array}$ & $\begin{array}{l}57.29 \pm 18.72 \\
61.09 \pm 20.16\end{array}$ & $0.224^{a}$ & $\begin{array}{l}56.33 \pm 7.88 \\
56.25 \pm 5.43\end{array}$ & $0.941^{a}$ \\
\hline $\begin{array}{l}\text { Involvement in extra } \\
\text { Activities }\end{array}$ & $\begin{array}{l}\text { Sports } \\
\text { Music } \\
\text { Tuition } \\
\text { Business }\end{array}$ & $\begin{array}{c}12 \\
17 \\
55 \\
4\end{array}$ & $\begin{array}{l}51.67 \pm 26.91 \\
58.82 \pm 15.76 \\
57.64 \pm 20.54 \\
55.00 \pm 10.00\end{array}$ & $0.791^{b}$ & $\begin{array}{c}59.00 \pm 7.31 \\
58.94 \pm 10.02 \\
54.40 \pm 5.39 \\
54.00 \pm 2.30\end{array}$ & $0.033^{b}$ \\
\hline $\begin{array}{l}\text { Duration of extra } \\
\text { activities/ day in } \\
\text { hours }\end{array}$ & $\begin{array}{l}<2 \\
2-4 \\
>4\end{array}$ & $\begin{array}{l}27 \\
49 \\
12\end{array}$ & $\begin{array}{l}57.46 \pm 21.78 \\
54.71 \pm 15.49 \\
57.50 \pm 19.12\end{array}$ & $0.882^{b}$ & $\begin{array}{l}56.54 \pm 6.99 \\
54.12 \pm 7.46 \\
55.17 \pm 5.87\end{array}$ & $0.420^{b}$ \\
\hline Subject affiliation & $\begin{array}{l}\text { Math } \\
\text { Science } \\
\text { Nepali } \\
\text { English } \\
\text { Social/Moral science } \\
\text { Others }\end{array}$ & $\begin{array}{l}35 \\
23 \\
36 \\
30 \\
24 \\
12\end{array}$ & $\begin{array}{l}57.71 \pm 20.30 \\
56.96 \pm 17.94 \\
62.50 \pm 20.19 \\
57.33 \pm 20.99 \\
59.58 \pm 17.56 \\
56.67 \pm 17.75\end{array}$ & $0.854^{b}$ & $\begin{array}{l}55.31 \pm 7.59 \\
57.39 \pm 7.94 \\
56.83 \pm 6.63 \\
55.60 \pm 5.83 \\
57.58 \pm 8.02 \\
54.67 \pm 4.77\end{array}$ & $0.670^{b}$ \\
\hline
\end{tabular}

${ }^{\mathrm{a}}$ Independent sample t test, $\quad{ }^{\mathrm{b}}$ One Way ANOVA

The study concluded that there was positive relationship $(r=0.455),(p=<0.001)$ between knowledge and attitude

increased; there is increment in positive attitude towards corporal punishment and vice versa. (Table 6) towards corporal punishment. This means when knowledge

Table 6 : Relationship between Knowledge and Attitude towards Corporal Punishment n=160

\begin{tabular}{|c|c|c}
\hline & \multicolumn{2}{|c|}{$\begin{array}{c}\text { Attitudes toward corporal punishment } \\
\text { r value }\end{array}$} \\
$\begin{array}{c}\text { Knowlue } \\
\text { punishment }\end{array}$ & 0.455 & $<0.001^{*}$
\end{tabular}

*Pearson's correlation is significant at the 0.05 level (2- tailed)

\section{DISCUSSION}

Although there are many child health worker in Nepal, very little survey exist in this context, testimonies as well as reported incidences in the media, suggest that corporal punishment is a common problem in many schools. This study was conducted to assess the existing knowledge and attitude regarding corporal punishment among primary school teachers. A semi-structured questionnaire to assess knowledge and five point Likert scale to assess attitude towards corporal punishment were used.

This study revealed that majority $(70 \%)$ of the respondents had experience of corporal punishment during their childhood. The result was consistent with the study of the 
Child Protection Alliance (CPA)-Gambia which reported that $97 \%$ of the respondents were beaten when they were students. ${ }^{6}$ Most (66.2\%) of the respondents had experienced canning, followed by ear pulling (13.2\%), knelling down (12.5\%), while $7.9 \%$ had done up-down with tugging ears as corporal punishment during their school life. Similar result was found by the study of Gagne M.H et.al which stated $66.4 \%$ of respondents experienced canning during their childhood. ${ }^{7}$

Study was found significant difference $(p=0.045)$ between gender and knowledge but did not find significant difference with attitude $(p=0.105)$. This result demonstrates that the gender factors affects the teachers' knowledge as well as mean score of attitude was more in female as compared to males but not significantly different. The results was consistent with the study result of Basci $Z$. and Dilekmen $\mathrm{M}^{8}{ }^{8}$ It might be due to female teachers tends to be more inclined to their role as teachers rather than their gender role of being female.

There was significant difference between age and teaching experience of respondents with attitude towards corporal punishment $(p=0.030)$. According to this finding, there were more positive attitudes towards corporal punishment among more than 40 years age group than that of lower age group. Similarly, more positive attitude found among those respondents who had teaching experience more than 20 years as compared to less than 10 years. Similar results stated in the study of Basci Z. and Dilekmen M. This may be because of the age and experience gives maturity in behavior. $^{8}$

There was significant difference in level of education of the respondents with knowledge $(p=0.002)$ but not with attitude $(p=0.192)$ towards corporal punishment. The result suggests that knowledge regarding corporal punishment increased with increasing level of education but attitude does not change significantly. This finding was supported by the study of Enrique G. and Herrero J. which stated that the respondents with higher education level were positive attitude towards corporal punishment; where as those with lower education appear to hold traditional views and more negative attitude.

There was significant difference between teachers' attitudes towards corporal punishment and working area $(p=0.002)$ as well as knowledge was more among government school teachers (mean 60.12 \pm 19.00 ) than that of private (mean \pm SD; $57.30 \pm 19.74$ ) but statistically not significant. The finding suggests that the government school teachers' had more positive attitude towards corporal punishment than the private schools. The result was consistent with the study result of UNICEF and CVICT, which reported that private schools' teachers' attitude was more negative and inflicts more severe physical punishment because such schools have greater social prestige and stricter reputation in the community. ${ }^{10}$

There was significant difference between training received with knowledge and attitude towards corporal punishment.
The result was consistent with the study result of Schmidt T. C. which reported in-service education program significantly increased the knowledge and perception of teachers towards corporal punishment. ${ }^{11}$ Training help the teachers to increase knowledge and improve their classroom organization, management skills, and teaching styles.

There was a significant difference in childhood experience of corporal punishment with knowledge and attitude towards corporal punishment. Those who had exposed to corporal punishment in childhood was found to have low knowledge (mean percentage score 56.16) and negative attitude (mean percentage score 55.32) towards corporal punishment as compared to those not exposed $(p=0.008$ and $p=0.006$ respectively). This finding was consistent with the study of Esther K Chung et.al which reported that childhood experience of corporal punishment was more likely to use punishment than those without such experiences. ${ }^{12}$ Another study of the CPA-Gambia also supported this finding which reported that $58.9 \%$ of teachers who were beaten as a student would use corporal punishment on their students and had negative attitude towards corporal punishment. ${ }^{13}$

The study results found a positive correlation between knowledge and attitude towards corporal punishment $(r=0.455),(p<0.001)$. The result was consistent with some studies by Halpenny, Ann Marie and Shahid S. M. that reported knowledge of teachers positively correlated with attitude. ${ }^{14}$ In contradictory to this finding Simiyu C.N. reported that the teachers had a negative attitude towards the corporal punishment despite their knowledge. ${ }^{15}$

\section{CONCLUSION}

This study revealed that knowledge and attitude towards corporal punishment was higher in females and those who received training with more teaching experience. So, teachers must be trained to increase knowledge and positive attitude towards corporal punishment. The population of experienced teachers can be increased by decreasing turnover rate of teachers through the governmental level. Similarly, the policy of government regarding recruitment of female teachers in primary level should be further promoted.

Those who experienced corporal punishment in childhood had a lower level of knowledge and negative attitude towards corporal punishment. The result supported an inter-generational cycle of punishment. When teachers use $\mathrm{CP}$ it teaches their students that hitting is an acceptable means of dealing with conflict.

From the findings, it can be seen that the attitude of teachers towards corporal punishment is still poor. They still believe that it improves a child's own self-discipline and it is culturally right to hit children. There is a need to draw the attention of the stakeholders for the developing the strong act against corporal punishment.

\section{RECOMMENDATIONS}

Teacher's training in disciplinary matter including positive reinforcement for appropriate behavior should be 
encouraged and made compulsory to all schools teachers. There is a need, for the government to initiate public awareness campaigns to disseminate information on corporal punishment as violence and a violent method of socializing children. The Ministry of Education should have a clear policy against prevention and elimination of corporal punishment from schools. Provision of female teachers in primary school seems to be further promoted. Regular school based awareness program about corporal punishment and its consequences on health of children was seen mandatory. For this purpose, health institution can work together with the school authority.

\section{REFERENCES}

1. Park K. Park's textbook of preventive and social medicine. 19th ed. Jabalpur; 2007.

2. Shrestha S. Thakuri S. Corporal Punishment in School: Hatamalo Sanchar. Kathmandu:; 2004 p. 23-50.

3. No corporal punishment please !!. APC Nepal. [Internet]. 2011 [updated on 2012 feb, cited 213 Jul 22]; Available from: http://apcnepal.org/enews/APC

4. Alyahri A, Goodman R. Harsh corporal punishment of Yemeni children: occurrence, type and associations. Child abuse \& neglect 2008 Aug;32(8):766-73.

5. Learn Without Fear: The global campaign to end violence in schools: Chobaham House, Christchurch way:Plan International; 2008. [cited 2013 Apr 24] p.88 Available from: http://plan-international. org/learnwithoutfear/files/learn-without-fear-global-campaignreport-

6. Tang J. Beating the Misconceptions, Not the Children [Internet]. The Gambia: 2005 [cited 2013 Aug]; Available from: http://www. academia.edu/997937/Beating_the_Misconceptions.

7. Gagné M-H, Tourigny M, Joly J, Pouliot-Lapointe J. Predictors of adult attitudes toward corporal punishment of children. Journal of interpersonal violence. 2007 Oct;22(10):1285-304.

\section{LIMITATION OF THE STUDY}

Since the study was conducted in urban, Biratnagar submetropolitan city, the findings cannot be generalized for all.

\section{ACKNOWLEDGEMENT}

We would like to acknowledge all respondents for their cooperation, time and participation who have been instrumental in the successful completion of this study.

\section{CONFLICT OF INTEREST}

We declare no conflict of interest.

8. Basci Zeynep and Dilekmen M. Attitude towards Corporal Punishment. world applied science Journal. 2009;7(6):933-8.

9. Herrero GE and J. Is it Considered Violence ? The Acceptability of Physical Punishment of Children in Europe. Journal of Marriage and Family. 2008;70(February):210-7.

10. A Study on the System of School Violence, discipline in Nepal. Kathmandu(Nepal); Center for Victims of Torture (CVICT); 2004 p. 52.

11. Suchmidt T.C. An assessment of the effectiveness of a corporal punishment inservice education program to school teachers. University Of Wisconsin,Wisconsin; 2000.

12. Chung EK, Mathew L, Rothkopf AC, Elo IT, Coyne JC, Culhane JF. Parenting attitudes and infant spanking: the influence of childhood experiences. Pediatrics [Internet]. 2009 Aug [cited 2013 Aug 18];124(2):e278-86. Available from: http://www.ncbi.nlm.nih. gov/pubmed

13. Tang J. Beating the Misconceptions, Not the Children [Internet]. The Gambia: 2005 [cited 2013 Aug]; Available from: http://www. academia.edu/997937/Beating the Misconceptions.

14. Halpenny, Ann Marie. Nixon, Elizabeth. watson D. The National Children's Strategy Research Series. Dublin; 2010 p. 1-120.

15. Christine $S$. Attitudes of teachers and pupils toward use of corporal punishment. University of Natal; 2003. p. 1-126. 